Ilmu Pertanian (Agricultural Science)

Vol. 1 No.1 April, 2016 : 031-036

Available online at http://journal.ugm.ac.id/jip

DOI: doi.org/10.22146/ipas.9912

\title{
Profitability and Farmers Conservation Efforts on Sustainable Potato Farming in Wonosobo Regency
}

\author{
Liana Fatma Leslie Pratiwi, Suhatmini Hardyastuti, Lestari Rahayu Waluyati \\ Magister Management of Agribusiness, Faculty of Agriculture, Universitas Gadjah Mada \\ Jln. Flora no. 1, Bulaksumur, Sleman, Yogyakarta 55281 \\ *Corresponding email: liana.fatma@gmail.com
}

Received: $4^{\text {th }}$ March 2016 ; Revised: $15^{\text {th }}$ March 2016 ; Accepted: $23^{\text {rd }}$ January 2017

\begin{abstract}
It takes into account in potato farming sustainability, since it was recognised as a holticultural commodity for farmers' subsistence in Wonosobo Regency. For the reason that farming land was being degraded by errossion, the potato productivity apparently continued to decline. Potato farming sustainability can be deliberated from economic (profitability) and environmental (conservation efforts) points of view in order to remain profitable in a long term sustainable environment. This study is aimed to (1) to analyse the profitability of potato farming; (2) to analyse farmers' effort on soil conservation and factors which affected sustainability of potato farming. The method used in this study was basic descriptive analysis. The study site was in Kejajar District, Wonosobo Regency, subsequently 50 random farmers as respondences was obtained. Gross Margin, Return on Invested Capital, and Operating Ratio were used to measure the profitability of potato farming. Conservation Activity Index (CAI) was used to measure farmers' effort on soil conservation, while paired liner regression model with Ordinary Least Square (OLS) method was used to understand the factors which affected the conservation efforts of test sites. The study results revealed that the potato farming was profitable. Farmers conservation efforts mostly was in average category (74\%), and only view in high category $(16 \%)$ and low category $(10 \%)$. Factors affected the farmers conservation efforts i.e. land area, potato products, potato price, the off-farm income, number of family members, farmers ages, and village dummy.
\end{abstract}

Keywords: Land Degradation, Potato Farming, Profitability, Soil Conservation, Wonosobo

\section{INTRODUCTION}

In various countries including Indonesia, there are many serious problems that threatened the sustainability of crop production. One of the serious problems is the occurrence of land degradation due to the effects of crop productivity, environmental quality, and subsequently affects food security. It is estimated up to $40 \%$ of the agricultural land existed in the world today has suffered from land degradation.

Land degradation is defined as the reduction of land capacity because it has explorated over its own ecologycal capacity. Land degradation inhibits plant growth (Khormali, 2009). Fragility of topsoil, affected by farm management such as fertilisation and cultivation process, causes erosion which deprieved topsoil of its soil nutrient content (Ferreras, 2007). Over application of pesticides reduces soil quality and it has to be controlled properly (Mosher, 1996; Van and Mendoza, 2003; Galt, 2008; VanderZaag,
2010).

Potato (Solanum tuberosum L.) is a horticultural commodity and also consumed by almost the whole population of the world. It is potentially grown and developed in Indonesia because the country has sufficient agroclimatic condition (Novary, 1997 cit. Sukayana et al., 2013; Ghadimi et al., 2014). Based on Statistic Indonesia (2013), Central Java produces the highest production of potato (273.513 ton) and Wonosobo is the central of its production. It has stable price with a good business prospect, suitable to be run in many levels of business capitals, the market was assured and certain, and has a long shelf life so farmers and investors are interested to cultivate potatoes. It leads to higher land requirements (Edi Syafril et al.,2003 cit. Razak et al., 2015). Land requirement is getting high and uncontrolled without any consideration of conservation area. In consequence, the land has suffered from serious degradation that caused a decreasing in environmental carrying capacity. 
Potato farming becomes main source of livelihood of the communities in Wonosobo. Sustainable livelihoods society can be achieved when income and welfare are increasing gradually (Sconnes, 1998). Because of it, it is important to maintain a sustainability of potatoes farm to help farmers livelihood. Sustainability must be seen from various aspects: the economy (profitability) and the environment (conservation efforts), so that in the long term sustainability of potato farming remains profitable and environment stable (Eltun et al., 2002; Saragih et al., 2007; VanderZaag, 2010). Potatoes farming needs to consider profitability and conservation practices (De Fauw et. al., 2012). The aims of the research are (1) to analyse the profitability of potato farming; (2) to analyse the farmers' effort on soil conservation and the influencing factors to farmers' effort on soil conservation which affected sustainability of potato farming.

\section{MATERIALS AND METHODS}

\section{Study Sites}

This research was conducted in the Kejajar district, Wonosobo regency as a region that has low, moderate, and high percentage of land degradation criteria. For sampling, two villages were taken as sample using purposive sampling. Serang and Surengede village were selected as study site because they had high potato production in 2013. Serang village's topography slopes were low $(<400)$ and moderate (400-700), while Surengede village's topography slopes were moderate (400-700) and high (> 700).

\section{Respondents}

The research population was farmers who cultivated potatoes. Respondents were chosen by simple random sampling. The number of samples taken were 25 farmers from each villages.

\section{Data Analysis \\ Profitability of Potato Farming}

Profitability of Potato Farming measured by Gross Margin (GM), Return on Invested Capital (ROIC), and Operating Ratio (OR) . It is formulated by :

a. Gross Margin (GM)

Gross Margin $(\mathrm{GM})=\mathrm{GFI}-\mathrm{TVC}$ in which :

$\mathrm{GM}=$ Gross Margin

GFI $=$ Gross Farm Income

$\mathrm{TVC}=$ Total Variabel Cost

b.Return on Invested Capital (ROIC)

Return on Invested Capital $(\mathrm{ROIC})=\frac{\mathrm{GM}}{\mathrm{TVC}}$...(1)

in which:
ROIC $=$ Return on Invested Capital

$\mathrm{GM}=$ Gross Margin

TVC $=$ Total Variabel Cost

c.Operating Ratio $(\mathrm{OR})$

Operating ratio $(\mathrm{OP})=\frac{\mathrm{TOC}}{\mathrm{GFI}}$

in which:

OR = Operating Ratio

TOC $=$ Total Operating Cost

GFI $=$ Gross Farm Income

Farmers Efforts in Soil Conservation to Maintain Sustainablity of Potato Farming

Conservation Activity Index (CAI) was used to determine farmers' soil conservation efforts and calculated using the formula :

$\mathrm{CAI}=\frac{\text { acquaired score }}{\text { maximum score }} \times 100 \%$

CAI was measured using 10 question types of soil conservation activities, namely: a) Plantation of reinforced terrace plants (b) Plantation of crops intersects slope (c) rotation of seasonal crops (d) Plantation of grass in the sewers (e) Mulch usage (f) Animal manure usage (g) Planting annual crops (h) Establishment of conservation buildings (i) Maintenance of conservation building (j) Tillage intersecting slope.

Factors Affecting Farmers' Effort In Soil Conservation To Maintain The Sustainability Of Potato Farming.

Multiple linear regression model with Ordinary Least Square method (OLS) was used to explain factors which affected farmers' soil conservation efforts. The model equations was described as:

$$
\begin{array}{r}
\mathrm{Y}=\alpha+\mathrm{b} 1 \mathrm{x} 1+\mathrm{b} 2 \mathrm{x} 2+\mathrm{b} 3 \mathrm{x} 3+\ldots+\mathrm{bn} \mathrm{xn}+\mathrm{d} 1 \mathrm{D} 1+ \\
\mathrm{d} 2 \mathrm{D} 2+\mathrm{d} 3 \mathrm{D} 3+\mu \ldots \ldots \ldots \ldots \ldots \ldots \ldots \ldots \ldots . .(4)
\end{array}
$$

in which:

$\mathrm{Y}=$ Conservation Activity Index (\%)

$\alpha=$ constant value

$\mathrm{b} 1, \mathrm{~b} 2, \mathrm{~b} 3, \ldots, \mathrm{bn}=$ coefficient regression

$\mathrm{X} 1=$ Land area (ha)

$\mathrm{X} 2$ = potato production $(\mathrm{kg} /$ year $)$

$\mathrm{X} 3=$ potato price $(\mathrm{Rp} / \mathrm{kg})$

$\mathrm{X} 4=$ Off farm income (Rp/year)

$\mathrm{X} 5$ = farmers' education (year)

$\mathrm{X} 6$ = farmers' age (year)

$\mathrm{X} 7=$ number of family members (people)

$\mathrm{X} 8$ = potato farming experience (year)

D1 = dummy variable of farmers group $(1=$ active and $0=$ non active)

D2 = dummy variable of credit access ( $1=$ available and $0=$ unavailable) 
Table 1. Potato Farming Profitability in Wonosobo Regency 2014 - 2015

\begin{tabular}{lccc}
\hline \multirow{2}{*}{ Description } & \multicolumn{3}{c}{ Profitability } \\
\cline { 2 - 4 } & $\begin{array}{c}\text { Gross Margin } \\
(\text { Rp) }\end{array}$ & $\begin{array}{c}\text { Return on } \\
\text { Invested Capital }\end{array}$ & Operating Ratio \\
\hline Mean & $62,188,000$ & 2.39 & 0.49 \\
Standard Deviation & $69,636,000$ & 3.30 & 0.34 \\
Minimun & $10,668,000$ & 0.26 & 0.05 \\
Maximum & $290,360,000$ & 20.39 & 1.36 \\
\hline
\end{tabular}

Source: Primary Data Analysis (2015)

D3 = dummy variable of status land owner $\operatorname{ship}(1=$ private property and $0=$ others $)$

D4 = dummy variable of village $(1=$ Serang and $0=$ Surangede)

$\mu \quad=$ error factor

Ordinary Least Square for regression needed classic assumption tests. They included normality test, multicollinearity, and heteroskedasticity. Adjusted $\mathrm{R} 2$ value, $\mathrm{F}$ test, and $\mathrm{t}$ test were used for hypothetical test.

\section{RESULT AND DISCUSSION}

\section{Profitability of Potato Farming}

Potato farming was the main livelihoods of farmers in Wonosobo and it contributed mostly in farmers income. Sustainability of potato farming was determined by economic aspect. If potatoes farming was not beneficial for farmers, it could be replaced by other more profitable crops. Profitability of potato farming in Wonosobo Regency was analysed and shown in Table 1.

Gross margin was used to measure the performance of farming in small scale. With gross margin calculation, the value of potato farming profitability per year was

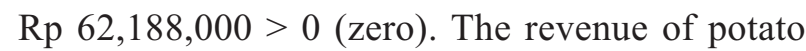
farming was greater than the variable costs and/or operational costs, so it can be concluded that potato farming was profitable.

The rate of capital return invested by farmers in potato farming found from the value of invested capital return, 2.39; every rupiah which was invested by farmers in potatoes farming amounted into 2.39 rupiah in gross margin, so that the farmers got twice from invested capital. It was concluded that potato farming was profitable. Beside two previous calculations, operating ratio was a ratio which was directly related to the level of input which was used such as seeds, fertilisers, pesticides, and labor. The lower the ratio, the higher the farming profitability. Operating ratio rate was 0.49 and that indicated potato farming was profitable enough and gave positive return for the capital amount which had been invested. Potato
Table 2. Percentage Farmers by Conservation Activity Index (CAI)

\begin{tabular}{lc}
\hline Category & Percentage (\%) \\
\hline Low $(\mathrm{CAI}<(\mu-\sigma))$ & 10 \\
Midle $((\mu-\sigma)<\mathrm{CAI}<(\mu+\sigma))$ & 74 \\
High $(\mathrm{CAI}>(\mu+\sigma))$ & 16 \\
\hline
\end{tabular}

Source: Primary Data Analysis (2015)

farming was profitable for farmers and prospective enough to be cultivated in long term, so from economic aspects view, potatoes farming was considered to be sustainable.

\section{Farmers Efforts in Soil Conservation to Maintain Sustainablity of Potato Farming}

Farmers in Wonosobo regency have been implementing soil conservation to increase land quality and productivity. Land degradation could be restored by performing soil conservation activities. The conservation efforts were measured by Conservation Activity Index (CAI). Farmers had practiced both vegetative and mechanical conservation techniques. The mean $(\mu)$ of conservation activity index (CAI) was $48.72 \%$ and its standard deviation $(\sigma)$ was $11.52 \%$

Based on the Table 2, 74\% farmers implemented soil conservation efforts in the midle category and the index of conservation activities ranged from 37.2 to $60.23 \%$, so most farmers applied more than half of top ten conservation efforts. Sixteen percent of farmers were in high category of conservation activity index (16\%) and $10 \%$ farmers were in a low category.

After decades of cultivating potatoes, farmers were aware of the danger of land degradation so farmers had begun to pay more attention to land condition and implemented soil conservation efforts. Farmers knew that their farming area was potentialy degraded so conservation efforts should be done to rehabilitate the farm area. Farmers which had high conservation value of the index were expected to participate in land preservation in order to avoid land degradation. 
Table 3. Regression Coefficient Of Factors Affecting Soil Conservation Efforts To Maintain The Sustainability Of Potato Farming In Wonosobo

\begin{tabular}{|c|c|c|}
\hline Variables & $\begin{array}{l}\text { Regression } \\
\text { Coefficient }\end{array}$ & Sig. $t$ \\
\hline Constanta & $16.314^{\mathrm{ns}}$ & 0.324 \\
\hline Land area $\left(\mathrm{X}_{1}\right)$ & $9.496^{*}$ & 0.002 \\
\hline Potato production $\left(\mathrm{X}_{2}\right)$ & $0.000^{* *}$ & 0.035 \\
\hline Potato price $\left(\mathrm{X}_{3}\right)$ & $0.008^{*}$ & 0.003 \\
\hline Off farm Income $\left(\mathrm{X}_{4}\right)$ & $-1.818 \mathrm{E}-7^{* * *}$ & 0.093 \\
\hline Farmer's education $\left(\mathrm{X}_{5}\right)$ & $-0.151^{\mathrm{ns}}$ & 0.823 \\
\hline Farmer's age $\left(\mathrm{X}_{6}\right)$ & $-0.367^{* *}$ & 0.016 \\
\hline Number of family members $\left(\mathrm{X}_{7}\right)$ & $-1.955^{* * *}$ & 0.082 \\
\hline Potato farming experience $\left(\mathrm{X}_{8}\right)$ & $0.242^{\text {ns }}$ & 0.168 \\
\hline Dummy of farmers group $(1=$ active and $0=$ non active $)\left(D_{1}\right)$ & $3.564^{\mathrm{ns}}$ & 0.262 \\
\hline Dummy credit access $(1=$ available and $0=$ unavailable $)\left(D_{2}\right)$ & $-0.903^{\mathrm{ns}}$ & 0.817 \\
\hline Dummy the land ownership $(1=$ their own land, $0=$ others $)\left(D_{3}\right)$ & $2.803^{\mathrm{ns}}$ & 0.406 \\
\hline Dummy village $(1=$ serang, $0=$ surengede $)\left(D_{4}\right)$ & $9.354^{* *}$ & 0.016 \\
\hline$\overline{A d j} R^{2}$ & \multicolumn{2}{|l|}{0.575} \\
\hline Sig. F & \multicolumn{2}{|c|}{0.000} \\
\hline \multicolumn{3}{|l|}{ Remark : } \\
\hline $\begin{array}{ll}* * *) & =\text { significant in } \alpha=10 \% \\
\text { ns } & =\text { non significant }\end{array}$ & & \\
\hline
\end{tabular}

Factors influencing conservation that maintain sustainability of potato farming

Soil conservation activities were necessary to maintain the sustainability of potato farming in Wonosobo regency. Sustainability potato farming in the long term was influenced by farmers conservation efforts. To improve conservation activity index by farmers, it was important to understand the influencing factors. Ordinary Least Squares (OLS) was used to analysed it, and it was shown in Table 3.

Table 3. explained that the conservation activities index were influenced $57.5 \%$ by independent variables and $42.5 \%$ was influenced by other variables outside the regression model. Partially, individual variables which affected CAI significantly were land, potato production, potato price, off-farm income, number of family members, age of farmers, and dummy of village $(\mathrm{p}<0.05)$.

\section{Land}

Agriculture was a natural asset which used by farmers to earn a living. The increasing of land area intensified conservation efforts. From the regression model, when farmers land increased 1 ha, conservation activities index increased $9.49 \%$. The narrower the farming land area, the lower the conservation efforts because farmers thought that conservation activities decreased farm land width and they should provide additional burden which caused higher costs.

\section{Potato Production}

Production affected farmers' conservation efforts, but the increasing number of potato production would not affect the change of soil conservation activities index. By cultivating potatoes indirectly, farmers had practiced conservation effort in mulch and manure usage. A large scale of exploitation was done by farmers to obtain high potatoes production. Farmers who had narrow areas focused on its production only, without any adoption on principles because the conservation inhibits growth of potatoes and the activity needed higher cost.

\section{Potato Price}

Increasing the potato price would increase farmers conservation efforts. When the potato price increased by Rp 1, the conservation activities index could be increased by $0.008 \%$. Due to the high price, it provided a greater revenue to farmers, so the excess of these revenues could be used in funding conservation activities. Farmers conservation efforts had positive correlation with commodities prices (Mulyoutami, 2004; Evizal et al., 2005).

\section{Off farm Income}

Off-farm income used as an additional income to suffice farmers households. If the off-farm income increased by Rp.1, it caused a decline in farmers conservation activity index by $-1.818 \mathrm{E}-7 \%$. The condition happened because farmers spent less time on their farm so they could not do soil conservation properly.

\section{Number of Family Member}

Larger number of family member would decrease farmers conservation activity index. An increasing of 1 person in the family would reduce the conservation activity index by $1.955 \%$. The more family members, the more farmers spent time in household, so they 
would decide to use their income to meet household needs.

\section{Farmers Age}

Farmers old age would decrease farmers conservation activity index. When age of the farmers increased 1 year, the conservation activity index reduced by $0.37 \%$. Increasing farmers age would lower their productivities due to the declining physical condition.

\section{Village}

There were two villages in this research. Conservation index conducted by farmers between two villages was different. In Serang village, farmers had a higher conservation efforts (9.54\%) than Surengede village. Due to the more number of ramp areas in Serang than in Surengede village, the conservation efforts were easier and cheaper. Farm land with various and steep slope in Surengede village caused some difficulties for farmers to carry out the conservation activities because it needed higher costs.

Farmers' education, Potato farming experience, Dummy of farmers group, Dummy credit access, Dummy the land ownership

The factors which did not affect farmers conservation efforts included farmers' education, potato farming experience, dummy of farmers group, dummy credit access, and dummy the land ownership. Farmers went to elemetary school, and only few farmers continued their studies until university. Potato farming experience was alike, circa 10-15 years. There were only 2 active farmers in a farmer group, and credit access was also accessible. There were many local banks and money lenders to get a loan. Lands ownership were generally their own, so farmers did not pay much attention to conservation.

\section{CONCLUSION}

Potato farming was profitable. The invested capital return was obviously obtained and it had a higher income compared to its operational budget. In conservation efforts aspect, most farmers were classified as middle category. It meant that farmers had applid half of ten soil conservation activities. Few farmers were in high category and few farmers were in a low category in implementing conservation efforts. Middle category showed that farmers were performing soil conservation activities with erratic behavior that meant sometimes farmers were performing soil conservation activities. Conservation activities often performed by farmers were manure dan mulch usage, conservation building establishment such as terrace, and annual crop rotation. Factors which affected farmers conservation efforts i.e. land area, potato products, potato price, the off-farm income, number of family members, farmers' ages, and village dummy. Variables positively affected farmers' conservation efforts including total land area, potato products, potato price, and village dummy; and variables negatively affected including off-farm income, number of family members, and farmers' ages.

\section{ACKNOWLEDGMENT}

Author would like to thank the laboratory of Department of Agricultural Socio-economics, Faculty of Agriculture UGM that gave permission to author to use a portion of the data for this paper and also for research team who helped in collecting data in Wonosobo, the local government that provides access to conduct the research and all of farmers who became respondents in this research.

\section{REFERENCES}

Badan Pusat Statistik Kabupaten Wonosobo. 2014. Wonosobo dalam Angka i2005-2014. Badan Pusat Statistik Kabupaten Wonosobo. Wonosobo.

DeFauw, S.L., Larkin, R.P., English, P.J., Halloran, J.M., and Hoshide, A.K. 2012. Geospatial evaluations of potato production systems in Maine. Springer : Potato Association of America. American Journal of Potato Research. 89 (6): 471-488.

Eltun, R., Korsæth, A., and Nordheim, O. 2002. A comparison of environmental, soil fertility, yield, and economical effects in six cropping systems based on an 8-year experiment in Norway. Elsevier Science. Agriculture, Ecosystems and Environment. 90 (2): 155168.

Evizal, R.S, Budidarsono and F.E Prasmatiwi. 2005. Land use history, intensity and socio-economic background of Sumberjaya Window, Lampung Benchmark. CSM-BGBD. Manaus, Brazil. 25p.

Ferreras, L., Magra, G., Besson, P., Kovalevski, E., and García, F. 2007. Physical quality indicators in soils from the Northern Pampa region of Argentina under no till management . Scopus. Ciencia del Suelo. 25 (2): 159-172.

Galt, Ryan E. 2008. Toward an integrated understanding of pesticide use intensity in Costa Rican vegetable farming. Springer Science Business Media. Human Ecology. 36 (5): 655 677.

Ghadimi, Seyed Alireza, Hossien Shabanali Fami, and Ali Asadi. 2014. Sustainable agriculture reviews: organic potato farming adoption in 
Iran. In: Eric Lichtfous (Eds). Springer International Publishing 15. Switzerland. 353-370.

Khormali, F., M. Ajami, S. Ayoubi, Ch. Srinivasarao c, S.P. and Wani. 2009. Role of deforestation and hillslope position on soil quality attributes of loess-derived soils in Golestan Province, Iran. Elsevier. Agriculture, Ecosystems and Environment. 134: 178-189.

Mosher, A.T. 1996. Getting Agriculture Moving. Frederick A. Prager Inc,. New York.

Mulyoutami, E.E. Stefanus, W. Schalenbourg, S. Rahayu, and L. Joshi. 2004. Pengetahuan petani lokal dan inovasi ekolohi dalam konservasi dan pengelolaan tanah pada pertanian berbasis kopi di Sumberjaya, Lampung Barat. Agrivita. 26 (1) : 98-107.

Razak, Zulkifli, A. R. Mappangaja, S Bulkis, and Baharuddin. 2015. Agribusiness development increasing the production of potato farmers In Gowa District, Indonesia. International Journal of Current Research and Academic Review. 3 (6) : $160-167$.

Saragih, Sebastian, Jonatan Lassa, dan Afan Ramli. 2007. Kerangka Penghidupan Berkelanjutan. $<$ http://www.zef.de/module/register/media/23
90 SL-Chapter1.pdf>. (Access December, 12 2011).

Sconnes, Ian. 1998. Sustainable Rural Livihood, A Frame for Analysis, IDS Working Paper 72. University of Sussex, Brighton.

Sukayana, I Made, Dwi Putra D, dan Ni Putu. 2013. Rantai nilai komoditas kentang granola di Desa Candi Kuning Kecamatan Baturiti Kabupaten Tabanan. E-Jurnal Agribisnis dan Agrowisata. 2 (3) : $99-108$.

Van Phu, H. and Mendoza. 2008. Soil erosion and nutrient management in farming systems of the northern uplands of Vietnam. Elsevier. Philippine Agricultural Scientist. 86 (2): 172181.

VanderZaag, Peter. 2010. Toward sustainable potato production: experience with alternative methods of pest and disease control on a commercial potato farm. Springer : Potato Association of America. American Journal of Potato Research. 87 (5): 428-433. 